\title{
Dual action of highbush blueberry proanthocyanidins on Aggregatibacter actinomycetemcomitans and the host inflammatory response
}

\author{
Amel Ben Lagha, Geneviève LeBel and Daniel Grenier*
}

\begin{abstract}
Background: The highbush blueberry (Vaccinium corymbosum) has a beneficial effect on several aspects of human health. The present study investigated the effects of highbush blueberry proanthocyanidins (PACs) on the virulence properties of Aggregatibacter actinomycetemcomitans and macrophage-associated inflammatory responses.

Methods: PACs were isolated from frozen highbush blueberries using solid-phase chromatography. A microplate dilution assay was performed to determine the effect of highbush blueberry PACs on A. actinomycetemcomitans growth as well as biofilm formation stained with crystal violet. Tight junction integrity of oral keratinocytes was assessed by measuring the transepithelial electrical resistance (TER), while macrophage viability was determined with a colorimetric MTT assay. Pro-inflammatory cytokine and MMP secretion by A. actinomycetemcomitans-stimulated macrophages was quantified by ELISA. The U937-3xkB-LUC monocyte cell line transfected with a luciferase reporter gene was used to monitor NF-kB activation.

Results: Highbush blueberry PACs reduced the growth of A. actinomycetemcomitans and prevented biofilm formation at sub-inhibitory concentrations. The treatment of pre-formed biofilms with the PACs resulted in a loss of bacterial viability. The antibacterial activity of the PACs appeared to involve damage to the bacterial cell membrane. The PACs protected the oral keratinocytes barrier integrity from damage caused by A. actinomycetemcomitans. The PACs also protected macrophages from the deleterious effect of leukotoxin LtX-A and dose-dependently inhibited the secretion of pro-inflammatory cytokines (IL-1 $\beta, I L-6, C X C L 8$, TNF-a), matrix metalloproteinases (MMP-3, MMP-9), and sTREM-1 by A. actinomycetemcomitans-treated macrophages. The PACs also inhibited the activation of the NF-kB signaling pathway.

Conclusion: The antibacterial and anti-inflammatory properties of highbush blueberry PACs as well as their ability to protect the oral keratinocyte barrier and neutralize leukotoxin activity suggest that they may be promising candidates as novel therapeutic agents.
\end{abstract}

Keywords: Aggregatibacter actinomycetemcomitans, Blueberry, Cytokine, Keratinocyte, Leukotoxin, Macrophages, Matrix metalloproteinase, Periodontal disease, Proanthocyanidins, Tight junction

* Correspondence: Daniel.Grenier@greb.ulaval.ca

Oral Ecology Research Group (GREB), Faculty of Dentistry, Université Laval,

2420 Rue de la Terrasse, Quebec City, QC G1V 0A6, Canada

(c) The Author(s). 2018 Open Access This article is distributed under the terms of the Creative Commons Attribution 4.0 International License (http://creativecommons.org/licenses/by/4.0/) which permits unrestricted use, distribution, and reproduction in any medium, provided you give appropriate credit to the original author(s) and the source, provide a link to the Creative Commons license, and indicate if changes were made. The Creative Commons Public Domain Dedication waiver (http://creativecommons.org/publicdomain/zero/1.0/) applies to the data made available in this article, unless otherwise stated. 


\section{Background}

Periodontal disease is a biofilm-induced chronic inflammatory disease characterized by the loss of the tooth-supporting tissues, including alveolar bone. The Gram-negative periodontopathogen Aggregatibacter actinomycetemcomitans is the key factor in the etiology of localized aggressive periodontitis $[1,2]$. This rapidlyprogressing form of periodontitis, which affects incisors and first molars in teenagers and young adults, has been linked to a genetic predisposition [3-6]. A. actinomycetemcomitans has also been associated with non-oral infections such as endocarditis, septicemia, pneumonia, infectious arthritis, osteomyelitis, and various types of abscesses [3-6].

A. actinomycetemcomitans expresses several virulence factors that enable it to colonize and invade oral tissues, avoid the host defense system, and cause tissue destruction [5]. Its ability to adhere to biotic and abiotic surfaces is an important factor for host colonization [7, 8]. Strains or mutants that are unable to adhere to oral tissues are also unable to colonize the oral cavity of the rat and to cause bone loss in a rat model of periodontitis $[9,10]$. A. actinomycetemcomitans can form biofilms that protect it from antibiotics commonly used in periodontal therapy [11]. It secretes a leukotoxin (LtxA) that selectively kills human leukocytes by inducing apoptosis and lysis [12]. It has also been suggested that there is an association between the leukotoxicity of A. actinomycetemcomitans and aggressive forms of periodontitis [12].

The gingival epithelium comprises the epithelial tissue that covers the external surface of the gingiva, the epithelium lining the gingival sulcus, and the junctional epithelium [13]. This structure plays a crucial protective role, acting as a mechanical and antimicrobial barrier that prevents the invasion of the periodontium by periodontopathogens [13]. Inflammation of the periodontium begins with the penetration of bacteria or their products through the epithelial lining [14, 15]. Macrophages and monocytes are the first line of host defenses against periodontal infections and play a key role in the initiation of an adaptive immune response [16]. When these cells are stimulated with A. actinomycetemcomitans, they secrete many pro-inflammatory cytokines, including tumor necrosis factor $\alpha$ (TNF- $\alpha)$, interleukin$1 \beta$ (IL-1 $\beta$ ), interleukin-6 (IL-6), and interleukin-8 (CXCL8) [17]. While the host response is involved in gingival tissue homeostasis, uncontrolled and excessive stimulation may lead to a chronic inflammatory state due to the secretion of large amounts of inflammatory mediators and matrix metalloproteinases (MMPs) by mucosal and immune cells, contributing to periodontal tissue destruction $[18,19]$.

The beneficial effects of bioactive plant food compounds on periodontal diseases have received considerable attention over the past 10 years [20]. Based on our current understanding of the etiology and pathogenesis of periodontitis, plant polyphenols may be highly promising candidates for use in adjunctive periodontal therapies. The highbush blueberry (Vaccinium corymbosum L.) is cultivated in many regions of the world and is one of the most commonly consumed berries in the United States, ranking second after strawberries in popularity [21]. Many studies have shown that blueberries have a positive effect on brain aging, diabetes, various cancers, and cardiovascular diseases [22-24]. Blueberries contain significant amounts of flavonoids, including anthocyanins, flavanols, flavonols, and proanthocyanidins (PACs) $[25,26]$, which likely contribute to the reported beneficial health effects in humans. PACs are some of the most abundant compounds in tea, apples, and berries. They are oligomers of catechin and epicatechin and their gallic acid esters. In the present study, we investigated the antibacterial and anti-biofilm effects of highbush blueberry PACs (hereafter simply referred to as PACs) against $A$. actinomycetemcomitans as well as the protective effects of PACs with regard to the breakdown of the integrity of the epithelial tight junction by A. actinomycetemcomitans as well as macrophage killing by the leukotoxin produced by this periodontopathogen. We also assessed the anti-inflammatory effects of PACs by evaluating the inhibition of NF- $\mathrm{kB}$ activation and cytokine/MMP secretion by monocytes/macrophages.

\section{Methods \\ Preparation of highbush blueberry PACs}

PACs were isolated from frozen highbush blueberries $(V$. corymbosum L.), produced by the Marucci Center for Blueberry and Cranberry Research (Rutgers University, Chatsworth, NJ), using solid-phase chromatography according to a well-established method for PAC isolation [27]. Electrospray mass spectrometry, ${ }^{13} \mathrm{C}$ NMR, matrixassisted laser desorption/ionization time-of-flight mass spectrometry and acid catalyzed degradation with phloroglucinol confirmed the purity of the PAC fraction [27]. Purified PACs were dissolved in 50\% ethanol at a final concentration of $10 \mathrm{mg} / \mathrm{ml}$ and were stored at $4{ }^{\circ} \mathrm{C}$ in the dark for up to 1 month. Preliminary experiments showed that at the dilutions used, the ethanol added had no effects on the assay described below.

\section{Bacteria and lipopolysaccharide preparation}

A. actinomycetemcomitans ATCC 29522 was grown anaerobically $\left(80 \% \mathrm{~N}_{2}: 10 \% \mathrm{CO}_{2}: 10 \% \mathrm{H}_{2}\right)$ for $24 \mathrm{~h}$ at $37{ }^{\circ} \mathrm{C}$ in Todd-Hewitt broth (THB; BD Diagnostics, USA) supplemented with $1 \%$ yeast extract. A. actinomycetemcomitans LPS was isolated using the protocol described by Darveau and Hancock [28]. It was dissolved at a 
concentration of $1 \mathrm{mg} / \mathrm{ml}$ in sterile distilled water and was stored at $-20{ }^{\circ} \mathrm{C}$ until used.

\section{Biofilm formation Microplate assay}

A. actinomycetemcomitans was grown in the wells of a 96-well microplate for $24 \mathrm{~h}$ under anaerobic conditions in the absence or presence of two-fold serial dilutions of PACs (500 to $3.9 \mu \mathrm{g} / \mathrm{ml}$ ). Bacterial growth was monitored by recording the optical density at $660 \mathrm{~nm}$ $\left(\mathrm{OD}_{660}\right)$ using a Synergy 2 microplate reader (BioTek Instruments, USA). Thereafter, medium containing freefloating bacteria was removed by aspiration using a $26 \mathrm{G}$ needle. The wells were washed three times with distilled water, and the biofilms were stained for $15 \mathrm{~min}$ with $100 \mu \mathrm{l}$ of $0.05 \%$ crystal violet. The wells were then rinsed three times with distilled water and were dried for $2 \mathrm{~h}$ at $37{ }^{\circ} \mathrm{C}$. Ethanol $(100 \mu \mathrm{l}, 95 \%[v / \mathrm{v}])$ was added to each well, and the plate was shaken for $10 \mathrm{~min}$ to release the dye from the biofilms. The absorbance at $550 \mathrm{~nm}\left(\mathrm{~A}_{550}\right)$ was recorded using a Synergy 2 microplate reader.

\section{Scanning electron microscopy}

The effect of PACs on A. actinomycetemcomitans biofilm formation was also examined by scanning electron microscopy. An overnight culture of A. actinomycetemcomitans suspended in fresh culture medium to an $\mathrm{OD}_{660}$ of 0.2 in the absence or presence of 31.25 or $62.5 \mu \mathrm{g} / \mathrm{ml}$ of PACs was added $(1 \mathrm{ml})$ to the wells of a 12-well microplate containing a sterile $13-\mathrm{mm}$-diameter plastic coverslip. After a 24-h incubation under anaerobiosis, the medium and free-floating bacteria were removed by aspiration, and the plastic coverslips were washed twice with $0.1 \mathrm{M}$ cacodylate buffer ( $\mathrm{pH}$ 7.2). The biofilm-coated coverslips were incubated for $3 \mathrm{~h}$ in fixation buffer $(2.5 \%[w / v]$ glutaraldehyde [grade I] and $1 \mathrm{mM} \mathrm{CaCl}_{2}$ in $0.1 \mathrm{M}$ cacodylate buffer, $\mathrm{pH}$ 7.2), washed three times (20 min each time) with $0.1 \mathrm{M}$ cacodylate buffer ( $\mathrm{pH}$ 7.2), and post-fixed for $90 \mathrm{~min}$ at room temperature in $1 \%[w / v]$ osmic acid containing $2 \mathrm{mM}$ potassium ferrocyanide and $6 \%[\mathrm{w} / \mathrm{v}]$ sucrose in cacodylate buffer. The samples were dehydrated using a graded series of ethanol $(50,70,95,100 \%)$, critical point-dried, gold-sputtered, and examined using a JEOL JSM6360LV scanning electron microscope operating at $30 \mathrm{kV}$.

\section{Biofilm viability and eradication}

We investigated the capacity of PACs to eradicate biofilms and kill biofilm-embedded bacteria. Briefly, 24-h A. actinomycetemcomitans pre-formed biofilms in the wells of a 96-well microplate were washed once with $50 \mathrm{mM}$ phosphate-buffered saline pH 7.2 (PBS) and were treated for $6 \mathrm{~h}$ under anaerobic conditions with PACs (500 to $31.25 \mu \mathrm{g} / \mathrm{ml})$. In order to assess biofilm eradication, a series of treated biofilms was washed twice with PBS and was stained with crystal violet as described above. A second series of treated biofilms was used to assess bacterial viability using a BacTiter-Glo ${ }^{\mathrm{Tm}}$ microbial cell viability assay kit (Promega Corporation, USA) in accordance with the manufacturer's protocol. Luminescence was monitored using a Synergy 2 microplate reader. Biofilms treated with PBS were used as controls.

\section{Cell membrane permeability assay}

The effect of PACs on the integrity of the A. actinomycetemcomitans membrane was determined using the intracellular dye calcein acetoxymethyl ester (calcein-AM) (Sigma-Aldrich Canada Co., Canada), as previously described [29]. Briefly, A. actinomycetemcomitans cells from a $10-\mathrm{ml}$ overnight culture were suspended in $5 \mathrm{ml}$ of PBS and were incubated anaerobically in the presence of $25 \mu \mathrm{l}$ of $1 \mathrm{mM}$ calcein-AM for $2 \mathrm{~h}$ at room temperature. The bacterial cells were then washed twice and were suspended to an $\mathrm{OD}_{660}$ of 0.2 in PBS. CalceinAM-loaded bacteria were placed $(100 \mu \mathrm{l})$ in the wells of a black wall black bottom 96-well microplate (Greiner Bio-One North America Inc., USA) and were incubated at room temperature in the presence of two-fold serial dilutions of PACs (250 to $31.25 \mu \mathrm{g} / \mathrm{ml})$. The release of calcein-AM caused by cell damage was monitored every $10 \mathrm{~min}$ for $240 \mathrm{~min}$ using a microplate reader, with the excitation wavelength set at $485 \mathrm{~nm}$ and the emission wavelength set at $530 \mathrm{~nm}$. PBS was used as a negative control while cells treated with chlorhexidine $(200 \mu \mathrm{g} /$ $\mathrm{ml}$ ) were used as a positive control.

\section{Oral keratinocyte tight junction integrity}

The previously characterized oral keratinocyte cell line B11 [30], which was kindly provided by S. Groeger (Justus-Liebig-University Giessen, Germany), was used to evaluate the effect of PACs on the integrity of the oral keratinocyte tight junction by determining the transepithelial electrical resistance (TER) [31]. Keratinocytes were cultured in keratinocyte serum-free medium (K-SFM; Life Technologies Inc., Canada) supplemented with growth factors $(50 \mu \mathrm{g} / \mathrm{ml}$ of bovine pituitary extract and $5 \mathrm{ng} / \mathrm{ml}$ of human epidermal growth factor) and $100 \mathrm{\mu g} / \mathrm{ml}$ of penicillin G-streptomycin at $37{ }^{\circ} \mathrm{C}$ in a $5 \%$ $\mathrm{CO}_{2}$ atmosphere. Keratinocytes $\left(3 \times 10^{5}\right.$ cells per insert $)$ were seeded on Costar ${ }^{\mathrm{Tm}} \mathrm{Transwell}^{\mathrm{Tm}}$ clear polyester membrane inserts $(6.5 \mathrm{~mm}$ in diameter, $0.4-\mu \mathrm{m}$ pore size; Corning Co., USA). The basolateral and apical compartments were filled with $0.6 \mathrm{ml}$ and $0.1 \mathrm{ml}$ of culture medium, respectively. Following a 72 -h incubation, the conditioned medium was replaced with antibiotic-free K-SFM and the keratinocytes were incubated for a further $16 \mathrm{~h}$. The TER values were then measured using an ohm/voltmeter (EVOM2; World Precision 
Instruments, USA) after $0,24,48$, and $72 \mathrm{~h}$. Resistance values were calculated in Ohms $(\Omega) / \mathrm{cm}^{2}$ by multiplying the resistance values by the surface area of the membrane filter. Results are expressed as the percentage of the basal control value measured at time $0 \mathrm{~h}(100 \%$ value). A. actinomycetemcomitans cells at multiplicity of infections (MOIs) of $10^{3}$ and $10^{4}$ were added to the medium in the apical compartment to determine the effect of A. actinomycetemcomitans on the integrity of the oral keratinocyte tight junction. The effect of combining PACs (125 to $31.25 \mu \mathrm{g} / \mathrm{ml})$ and A. actinomycetemcomitans (MOI of $10^{4}$ ) was also tested. These concentrations were used based on preliminary assays showing that $\leq 125 \mu \mathrm{g} / \mathrm{ml}$ of PACs had no effect on the viability of B11 cells as determined using an MTT (3-[4,5-diethylthiazol2-yl]-2,5diphenyltetrazolium bromide) colorimetric assay (Roche Diagnostics, Canada).

\section{Immunofluorescent staining of zonula occludens-1 and occludin}

The oral keratinocytes treated for $24 \mathrm{~h}$ as described above were immunostained for two tight junction proteins, zonula occludens-1 and occludin. Briefly, cells were fixed in PBS containing 4\% paraformaldhehyde for $20 \mathrm{~min}$, permeabilized with $0.1 \%$ Triton-X100 for $10 \mathrm{~min}$, and blocked in 3\% nonfat milk in $20 \mathrm{mM}$ Tris hydrochloride buffer - $150 \mathrm{mM} \mathrm{NaCl}-0.5 \%$ Tween 20 $(\mathrm{pH} 8)$ for $40 \mathrm{~min}$. The cells were labeled with antioccludin antibody - Alexa Fluor 488 (331511) conjugate and anti-ZO-1 antibody - Alexa Fluor 594 conjugate (ZO-1-1A12) at $2.5 \mu \mathrm{g} / \mathrm{ml}$ in blocking buffer for overnight at $4{ }^{\circ} \mathrm{C}$. Then, the cells were washed with PBS and treated with the ProLong ${ }^{\circ}$ Diamond antifade (Life Technologies Inc.,), and the slides were sealed with a coverslip using nail polish and kept in the dark at $4{ }^{\circ} \mathrm{C}$. After washing with PBS, the localization of tight junction proteins in B11 cells was visualized using an Olympus FSX100 fluorescence microscope and FSX-BSW imaging software (Olympus, Tokyo, Japan).

\section{Purification of LtxA from A. actinomycetemcomitans}

Leukotoxin (LtxA) was purified from a culture supernatant of A. actinomycetemcomitans strain JP2 as previously described [32]. The protein concentration of the purified LtxA was determined using a Pierce ${ }^{\mathrm{Tm}}$ BCA Protein assay kit according to the manufacturer's protocol (Thermo Fisher Scientific, Canada). The purity of the LtxA preparation was assessed by SDS-12\% polyacrylamide gel electrophoresis (PAGE) and Coomassie blue staining.

\section{Effect of LtxA on macrophage viability}

U937 human monocytes (American Type Culture Collection, USA; CRL-1593.2) were cultivated in Roswell Park Memorial Institute 1640 medium (RPMI-1640; Life
Technologies Inc.) supplemented with $10 \%$ heatinactivated fetal bovine serum (FBS) and $100 \mu \mathrm{g} / \mathrm{ml}$ of penicillin $\mathrm{G} /$ streptomycin at $37{ }^{\circ} \mathrm{C}$ in a $5 \% \mathrm{CO}_{2}$ atmosphere. The monocytes $\left(2.5 \times 10^{5} \quad\right.$ cells $\left./ \mathrm{ml}\right)$ were incubated in RPMI-10\% FBS containing $100 \mathrm{ng} / \mathrm{ml}$ of phorbol myristic acid (PMA; Sigma-Aldrich, Canada) for $48 \mathrm{~h}$ to induce differentiation into adherent macrophagelike cells [33]. The adherent macrophage-like cells were detached by scraping, and were washed, suspended in RPMI-1\% FBS at a concentration of $1 \times 10^{6}$ cells $/ \mathrm{ml}$, seeded into the wells of a 96-well microplate $\left(1 \times 10^{5}\right.$ cells/well), and incubated overnight at $37^{\circ} \mathrm{C}$ in a $5 \% \mathrm{CO}_{2}$ atmosphere. To evaluate the ability of PACs to prevent LtxA-induced cytolysis, the macrophage-like cells were incubated for $60 \mathrm{~min}$ at $37{ }^{\circ} \mathrm{C}$ in a $5 \% \mathrm{CO}_{2}$ atmosphere in the presence of $1 \mu \mathrm{g} / \mathrm{ml}$ of LtxA together with serial dilutions of PACs (500 to $3.9 \mu \mathrm{g} / \mathrm{ml}$; in RPMI supplemented with 1\% FBS). Wells with no LtxA or PACs were used as controls. LtxA-induced cell death was monitored using the colorimetric MTT assay.

\section{Cytokine and MMP secretion by macrophages}

Adherent macrophage-like cells were prepared and were harvested as described above. The cells were suspended in RPMI-1\% FBS at a concentration of $1 \times 10^{6}$ cells $/ \mathrm{ml}$, seeded in the wells of a 12-well microplate $\left(1 \times 10^{6}\right.$ cells/ well), and incubated overnight at $37{ }^{\circ} \mathrm{C}$ in a $5 \% \mathrm{CO}_{2}$ atmosphere. To exclude the possibility that PAC-associated toxicity might cause a decrease in cytokine and MMP levels, the viability of PAC-treated macrophages was assessed using an MTT assay. The macrophage-like cells were pre-treated for $2 \mathrm{~h}$ with PACs $(125$ to $31.25 \mu \mathrm{g} / \mathrm{ml}$ ) prior to being stimulated with A. actinomycetemcomitans at an MOI of 100. An assay using a commercial inhibitor (BAY-11-7082; $25 \mu \mathrm{M}$; EMD Millipore Canada, Canada) was used as a positive control for the inhibition of cytokine and MMP secretion. Cells incubated in culture medium with or without PACs and stimulated or not with bacteria were used as controls. After a $24-\mathrm{h}$ incubation at $37{ }^{\circ} \mathrm{C}$ in a $5 \% \mathrm{CO}_{2}$ atmosphere, the culture medium supernatants were collected and were stored at $-20{ }^{\circ} \mathrm{C}$ until used. Enzyme-linked immunosorbent assay (ELISA) kits (eBioscience Inc., USA, and R\&D Systems, USA) were used to determine IL-1 $\beta$, IL-6, CXCL8, TNF- $\alpha$, MMP-3, and MMP-9 concentrations according to the manufacturers' protocols.

\section{Activation of the NF-KB transcription factor}

The human monoblastic leukemia cell line U937 3xкB-LUC, a subclone of the U937 cell line stably transfected with a luciferase gene coupled to a promoter of three NF-kB-binding sites, was kindly provided by R. Blomhoff (University of Oslo, Norway) [34]. The cells 
were routinely cultivated in RPMI-1640 supplemented with $10 \%$ heat-inactivated FBS, $100 \mu \mathrm{g} / \mathrm{ml}$ of penicillin $\mathrm{G} /$ streptomycin, and $75 \mu \mathrm{g} / \mathrm{ml}$ of hygromycin B at $37^{\circ} \mathrm{C}$ in a $5 \% \mathrm{CO}_{2}$ atmosphere. The effect of two-fold serial dilutions (500 to $3.9 \mu \mathrm{g} / \mathrm{ml}$ ) of PACs on U937 3xкB-LUC viability was first determined using an MTT assay to identify non-cytotoxic concentrations. To induce the activation of the NF- $\mathrm{kB}$ transcription factor, the U937 $3 \times x^{2} B-L U C$ cells $\left(10^{6}\right.$ cells/well) were seeded in the wells of a black wall, black bottom 96-well microplate and were stimulated for $6 \mathrm{~h}$ with $A$. actinomycetemcomitans LPS $(1,10,100$, and $1000 \mathrm{ng} / \mathrm{ml})$. To investigate the effect of PACs on A. actinomycetemcomitans LPS-induced NF-kB activation, U937 3xкB-LUC cells were preincubated with two-fold serial dilutions of PACs (125 to $3.9 \mu \mathrm{g} / \mathrm{ml}$; in RPMI-1\% FBS) for $30 \mathrm{~min}$ and were then stimulated for $6 \mathrm{~h}$ with LPS $(1 \mu \mathrm{g} / \mathrm{ml})$. Wells with no LPS or PACs were used as controls to determine basal NF- $\mathrm{kB}$ activity. An assay using the commercial inhibitor BAY-11-7082 $(25 \mu \mathrm{M})$ was used as a positive control for the inhibition of the NF- $\mathrm{KB}$ signaling pathway. NF- $\mathrm{kB}$ activation was determined by measuring luciferase activity following the addition Bright-Glo ${ }^{\text {na }}$ reagent (Promega Corporation, USA) in accordance with the manufacturer's protocol. Luminescence was monitored using a Synergy 2 microplate reader.

\section{Statistical analysis}

Unless indicated otherwise, all experiments were performed in triplicate in three independent experiments. The data are expressed as means \pm standard deviations
(SD). Statistical analyses were performed using a oneway ANOVA analysis of variance with a post hoc Bonferroni multiple comparison test (GraphPad Software Inc., USA). All results were considered statistically significant at $p<0.01$ or $p<0.001$.

\section{Results}

The ability of the PACs to interfere with the growth of A. actinomycetemcomitans was assessed first. At a concentration of $500 \mu \mathrm{g} / \mathrm{ml}$, the PACs reduced the growth of A. actinomycetemcomitans by $62.5 \%$ (Fig. 1a). To identify the mechanism by which PACs exert their antimicrobial activity against $A$. actinomycetemcomitans, we investigated the effect of the PACs on the cytoplasmic membrane integrity of $A$. actinomycetemcomitans using the fluorescent dye calcein-AM. The addition of the PACs to calcein-AM-loaded $A$. actinomycetemcomitans caused a dose- and time-dependent release of fluorescence, suggesting that cell lysis had occurred (Fig. 2). The release of calcein-AM increased 3.73-fold following a 3-h exposure of the bacteria to $125 \mu \mathrm{g} / \mathrm{ml}$ of PACs.

We then tested the effect of the PACs on biofilm formation by A. actinomycetemcomitans (Fig. 1a). The PACs at concentrations ranging from 500 to $3.9 \mu \mathrm{g} / \mathrm{ml}$ significantly and dose-dependently reduced biofilm formation. More specifically, $31.25 \mu \mathrm{g} / \mathrm{ml}$ of the PACs reduced the growth of $A$. actinomycetemcomitans by $23.83 \%$ and inhibited biofilm formation by $93.98 \%$. The effect of the PACs on biofilm formation was also visualized by scanning electron microscopy. Electron micrographs clearly showed that there is a marked reduction
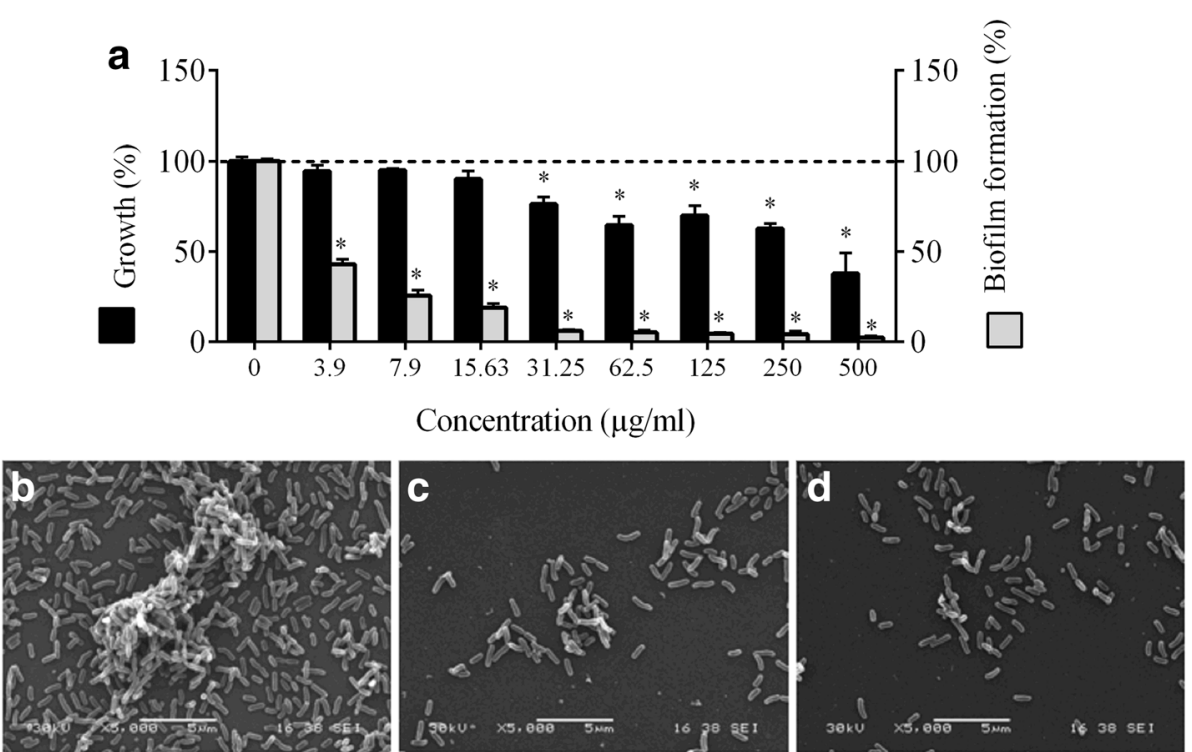

Fig. 1 Effect of highbush blueberry PACs on A. actinomycetemcomitans growth and biofilm formation (panel a). $*$ : significantly different $(p<0.01)$ from the control (no PACs). Scanning electron micrographs of A. actinomycetemcomitans biofilms formed in the absence (panel $\mathbf{b}$ ) and presence of $31.25 \mu \mathrm{g} / \mathrm{ml}$ (panel c) and $62.5 \mu \mathrm{g} / \mathrm{ml}$ of highbush blueberry PACs (panel d) 


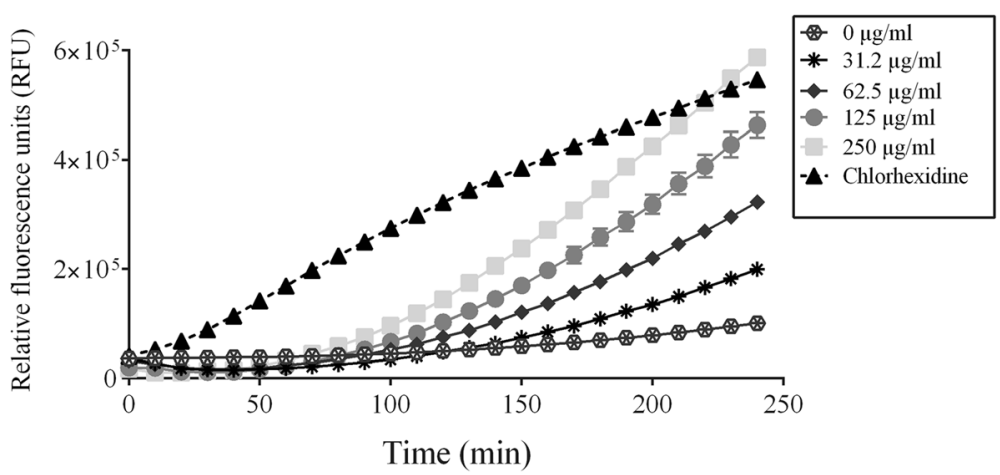

Fig. 2 Time-course release of calcein-AM by A. actinomycetemcomitans cells treated with various concentrations of highbush blueberry PACs. Chlorhexidine $(200 \mathrm{\mu g} / \mathrm{ml})$ was used as a positive control. A significant $(p<0.01)$ release of calcein-AM was observed with PACs at $62.5,125$, and $250 \mathrm{\mu g} / \mathrm{ml}$ following a treatment of bacteria for $120 \mathrm{~min}$. To obtain the same significance, a treatment of $160 \mathrm{~min}$ was necessary when PACs were used at $31.25 \mu \mathrm{g} / \mathrm{ml}$

in mature biofilms and that the architecture of the biofilms is disrupted when $A$. actinomycetemcomitans is grown in the presence of the PACs (Fig. 1b).

Given that the PACs reduced biofilm formation by $A$. actinomycetemcomitans, we then investigated their capacity to promote biofilm desorption and reduce biofilm viability. No desorption was observed when a preformed $A$. actinomycetemcomitans biofilm was treated with the PACs (up to $500 \mu \mathrm{g} / \mathrm{ml}$ ) for $6 \mathrm{~h}$ (Fig. 3). However, the treatment resulted in a dose-dependent loss of biofilm viability. More specifically, $500 \mu \mathrm{g} / \mathrm{ml}$ of the PACs reduced biofilm viability by $29.32 \%$.

Since periodontopathogens may have deleterious effects on the integrity of the oral keratinocyte tight junction, we determined whether the PACs protect the tight junction from such damage. Figure 4a shows the effect of A. actinomycetemcomitans at MOIs of $10^{3}$ and $10^{4}$ on the TER of keratinocytes following apical stimulation with bacteria. The TER values decreased in a concentration- and time-dependent manner in the presence of $A$. actinomycetemcomitans. Following a 48-h incubation, A. actinomycetemcomitans at an MOI of $10^{4}$ decreased the TER by
82.43\% while an MOI of $10^{3}$ decreased the TER by $10.28 \%$. We then examined the protective effect of the PACs when keratinocytes are challenged with A. actinomycetemcomitans at an MOI of $10^{4}$. As shown in Fig. 4b, the PACs attenuated the effect of A. actinomycetemcomitans in a concentration- and time-dependent manner. For example, $62.5 \mu \mathrm{g} / \mathrm{ml}$ of the PACs reduced the ability of $A$. actinomycetemcomitans to decrease the TER by 2.9 -fold and 4.1 -fold after 24 and $48 \mathrm{~h}$, respectively.

Immunostaining of $\mathrm{ZO}-1$ and occludin was performed to determine whether A. actinomycetemcomitans affect the oral keratinocyte barrier integrity through disruption of these tight junction proteins. As shown in Fig. 4c, a 24-h treatment of keratinocytes with A. actinomycetemcomitans (MOI of $10^{4}$ ) was associated with a decreased labeling of both ZO-1 and occludin However, the presence of PACs prevented this decreased labeling. At a concentration of $31.25 \mu \mathrm{g} / \mathrm{ml}$, PACs allowed a marked labeling suggesting the maintenance of expression of ZO-1 and occludin.

A. actinomycetemcomitans LtxA is considered a major virulence factor because of its ability to kill

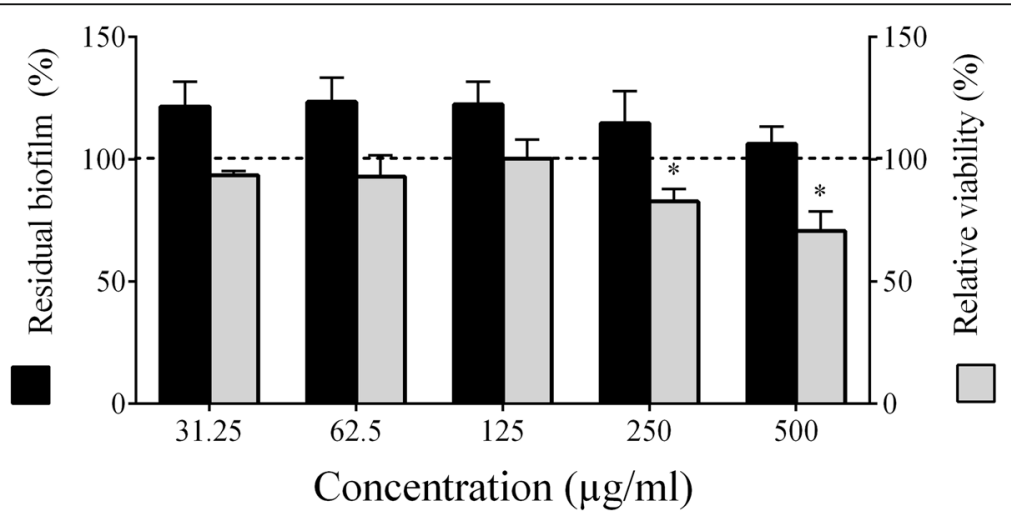

Fig. 3 Effect of highbush blueberry PACs on A. actinomycetemcomitans biofilm desorption and viability. $*$ : significantly different $(p<0.01)$ from the control (no PACs; horizontal line) 


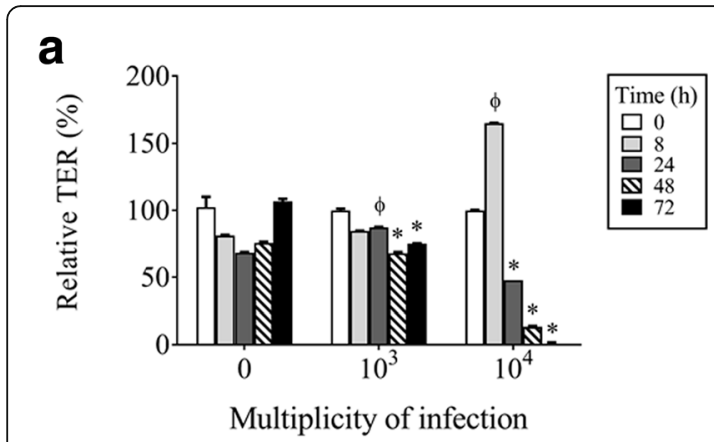

C

\section{A. actinomycetemcomitans}

Blueberry PACs $(\mu \mathrm{g} / \mathrm{ml})$

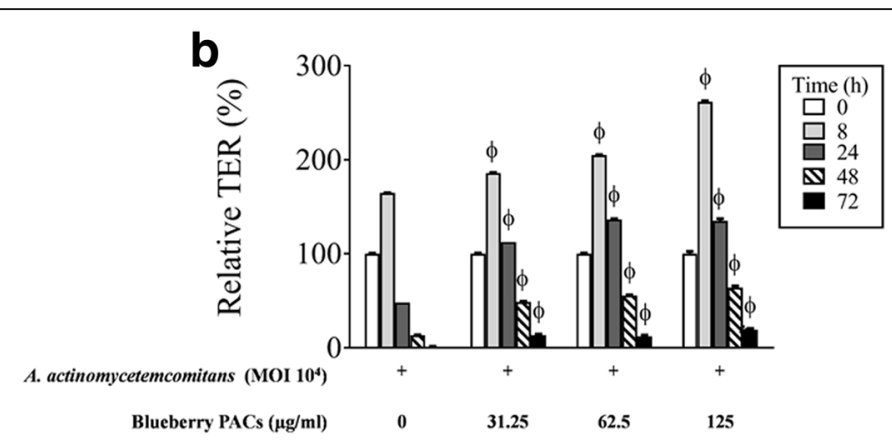

b

lueberry PACs $(\mu \mathrm{g} / \mathrm{m}$

$2.5 \quad 125$
0
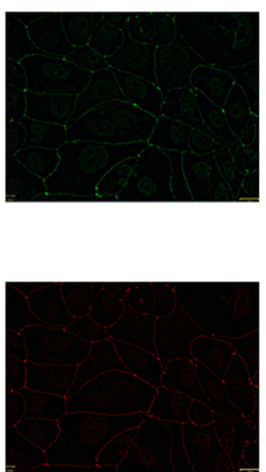

$+$

0
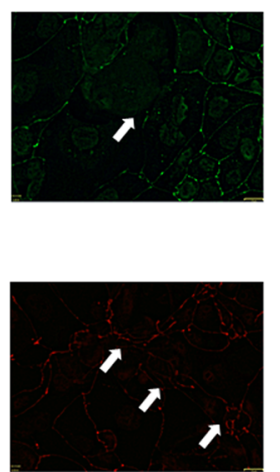

$+$

15.625
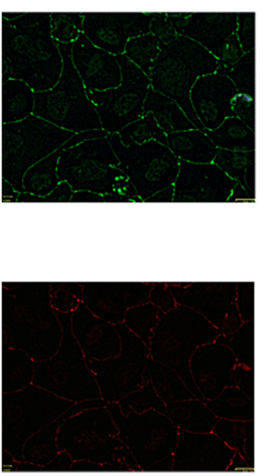

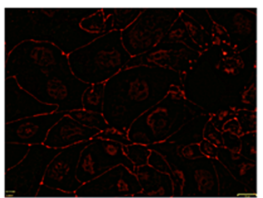

Fig. 4 Effect of A. actinomycetemcomitans in the absence and presence of highbush blueberry PACs on the integrity of the oral keratinocyte tight junction. Panel a: Effects of time and the number of A. actinomycetemcomitans cells on the transepithelial electrical resistance (TER) of oral keratinocytes. Panel b: Inhibitory effect of highbush blueberry PACs on the A. actinomycetemcomitans-induced decrease in the TER of oral keratinocytes. Panel c: Immunofluorescence staining of tight junction proteins occludin and zonula occludens-1 (ZO-1) of oral keratinocytes infected (24 h) by A. actinomycetemcomitans in the absence and presence of blueberry PACs. A 100\% value was assigned to the TER at time 0 . Results are expressed as the mean \pm SD of triplicate assays. $\Phi$ : significant increase $(p<0.001)$ compared with unstimulated control cells $(\mathbf{a})$ or with A. actinomycetemcomitans-stimulated cells not treated with highbush blueberry PACs (B). *: significant decrease $(p<0.001)$ compared with unstimulated control cells

macrophages. We thus determined whether the PACs can reduce LtxA cytotoxic activity. We showed that $1 \mu \mathrm{g} / \mathrm{ml}$ of LtxA reduced the viability of macrophagelike cells by $88.26 \%$ (Fig. 5), while the PACs exhibited a marked capacity to attenuate LtxA activity. More specifically, $125,62.5$, and $31.25 \mu \mathrm{g} / \mathrm{ml}$ of the PACs reduced the toxicity of LtxA by $100 \%, 95.4 \%$, and $69.70 \%$, respectively (Fig. 5).

We investigated the ability of the PACs to reduce the A. actinomycetemcomitans LPS-induced inflammatory response of macrophages. Adherent macrophage-like cells were pre-treated for $2 \mathrm{~h}$ with the PACs and were then stimulated for $24 \mathrm{~h}$ with $1 \mu \mathrm{g} / \mathrm{ml}$ of LPS. Secreted pro-inflammatory cytokines (IL-1 $\beta$, TNF- $\alpha$, IL-6 and CXCL8) and MMPs (MMP-3 and MMP-9) were then quantified by ELISA. To exclude the possibility that PAC-related toxicity may have an effect on cytokine and MMP levels, non-cytotoxic concentrations of PACs were determined. PAC concentrations up to $125 \mu \mathrm{g} / \mathrm{ml}$ had no effect on macrophage viability, which was $\geq 84.40 \pm 12.26 \%$ compared with the untreated controls (data not shown). The secretion of pro-inflammatory cytokines (IL-1 $\beta$, TNF- $\alpha$, IL-6, CXCL8) by macrophages stimulated with $A$. actinomycetemcomitans LPS was significantly and dose-dependently attenuated by the PACs compared to the controls. At a concentration of $125 \mu \mathrm{g} /$ $\mathrm{ml}$, the PACs reduced the secretion of IL- $1 \beta$, TNF- $\alpha$, IL-6, and CXCL8 by $75.34 \%$ (Fig. 6a), 81.64\% (Fig. 6b), $48.27 \%$ (Fig. 6c), and 90.19\% (Fig. 6d), respectively. Lastly, MMP-3 and MMP-9 secretion by A. actinomycetemcomitans LPS-stimulated macrophages was also attenuated by the PACs, in some cases below basal levels. More specifically, 125 and $62.5 \mu \mathrm{g} / \mathrm{ml}$ of the PACs reduced the secretion of MMP-3 by $93.04 \%$ and $54.57 \%$, respectively (Fig. 7a), and the secretion of MMP-9 by $68.78 \%$ and $14.07 \%$, respectively (Fig. $7 \mathrm{~b}$ ). 


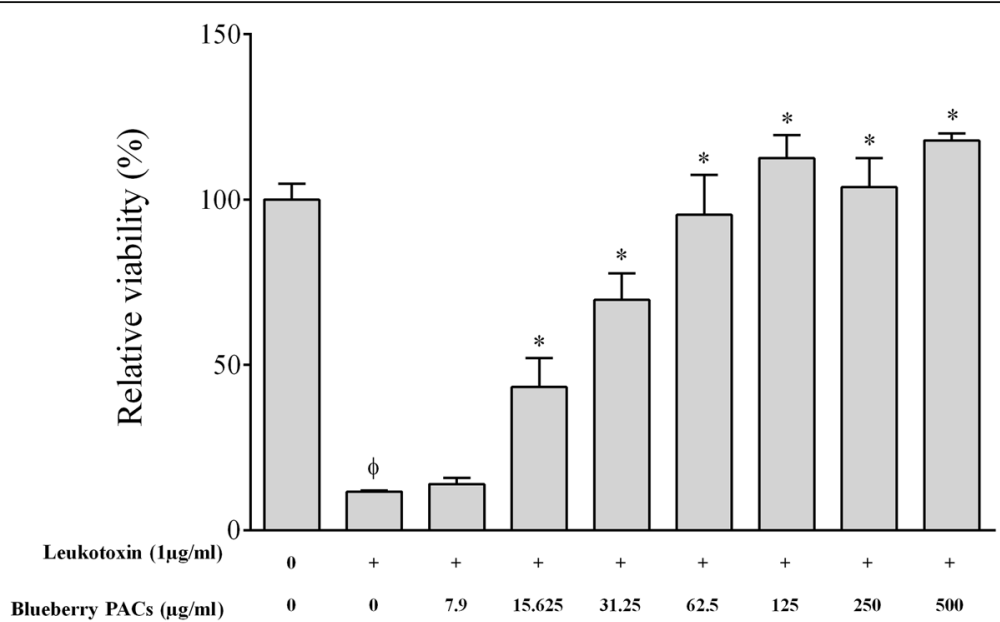

Fig. 5 Effect of highbush blueberry PACs on A. actinomycetemcomitans leukotoxin (LtxA) activity on macrophage-like cells. Ф: significant loss of cell viability $(p<0.001)$ compared to control cells not treated with LtxA. *: significant increase of cell viability $(p<0.001)$ compared to cells treated with LtXA

We also investigated the ability of the PACs to inhibit the secretion/shedding of sTREM-1 induced by the stimulation of macrophages with $A$. actinomycetemcomitans LPS. As shown in Fig. 8, A. actinomycetemcomitans LPS significantly increased the secretion/shedding of
sTREM-1 (1.3 fold), while 125 and $62.5 \mu \mathrm{g} / \mathrm{ml}$ of the PACs inhibited the secretion/shedding of sTREM-1 by $33.62 \%$ and $8.83 \%$, respectively.

Lastly, given that the NF- $\mathrm{kB}$ signaling pathway plays a key role in inflammatory processes leading to the

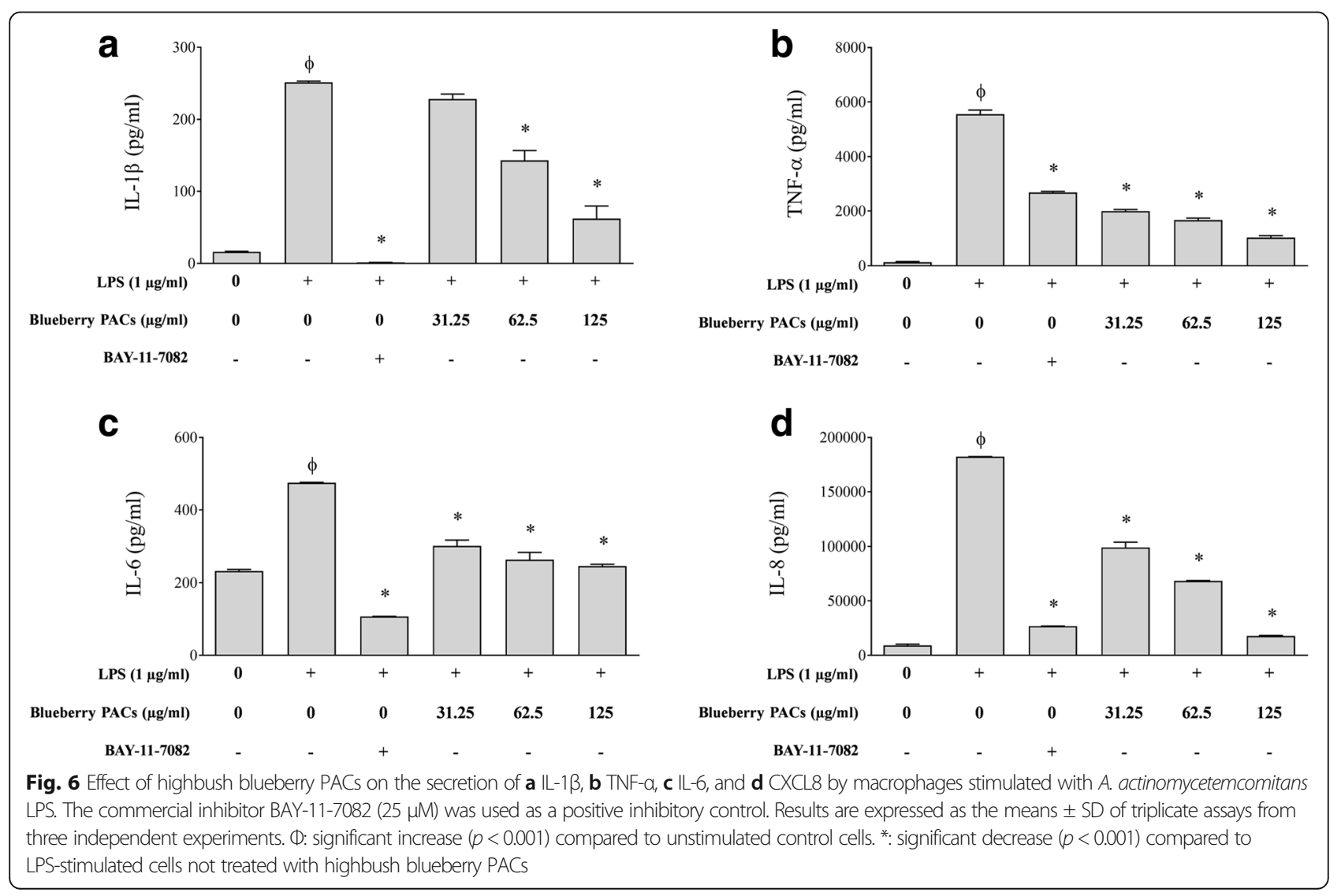




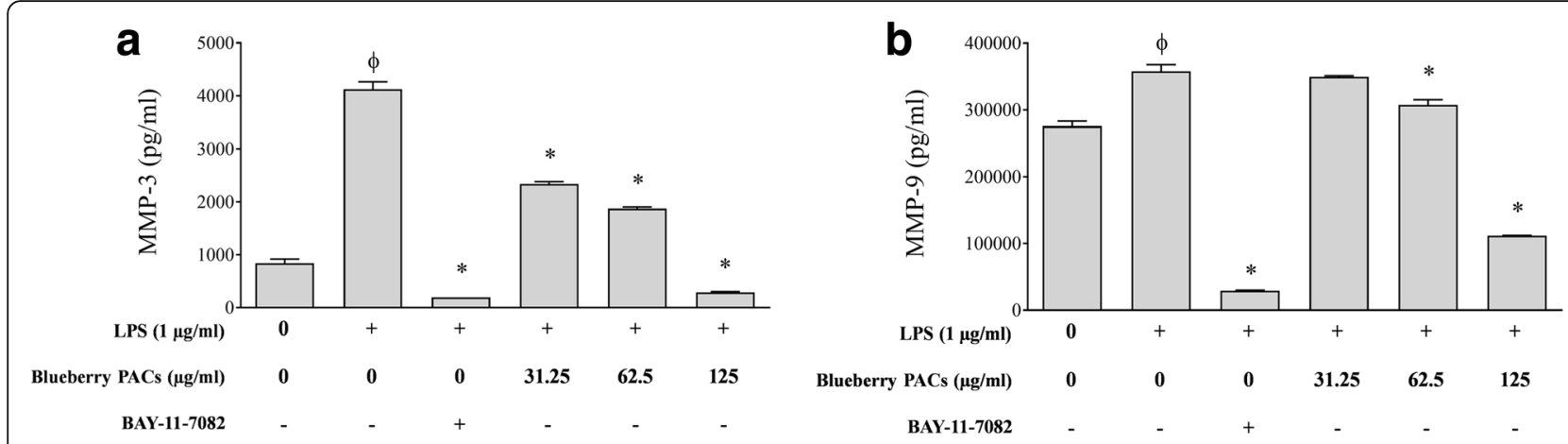

Fig. 7 Effect of highbush blueberry PACs on the secretion of a MMP-3 and $\mathbf{b}$ MMP-9 by macrophages stimulated with A. actinomycetemcomitans LPS. The commercial inhibitor BAY-11-7082 (25 $\mu \mathrm{M})$ was used as a positive inhibitory control. Results are expressed as the means \pm SD of triplicate assays from three independent experiments. $\Phi$ : significant increase $(p<0.001)$ compared to unstimulated control cells. *: significant decrease $(p<0.001)$ compared to LPSstimulated cells not treated with highbush blueberry PACs

secretion of cytokines and MMPs, we investigated the effect of the PACs on the activation of this transcription factor using the U937-3xкB-LUC cell line transfected with a luciferase reporter gene. As shown in Fig. $9 \mathrm{a}, 1 \mu \mathrm{g} / \mathrm{ml}$ of LPS activated the NF-kB signaling pathway by 24.95 -fold. We then determined whether the PACs prevented $A$. actinomycetemcomitans LPS-induced NF- $\mathrm{kB}$ activation in U937-3xkB cells. The PACs dose-dependently inhibited the activation of NF- $\mathrm{KB}$ signaling pathway induced by LPS. More specially, 125, 62.5, 31.25, and $15.625 \mu \mathrm{g} / \mathrm{ml}$ of the PACs reduced NF-kB activation by $62.69 \%, 62.82 \%$, $54.26 \%$, and $37.94 \%$, respectively (Fig. $9 \mathrm{~b}$ ). As expected, the commercial inhibitor BAY-11-7082 $(25 \mu \mathrm{M})$ completely prevented NF- $\mathrm{kB}$ activation.

\section{Discussion}

The highbush blueberry ( $V$. corymbosum L.), which is mostly grown in the United States, Canada, and South

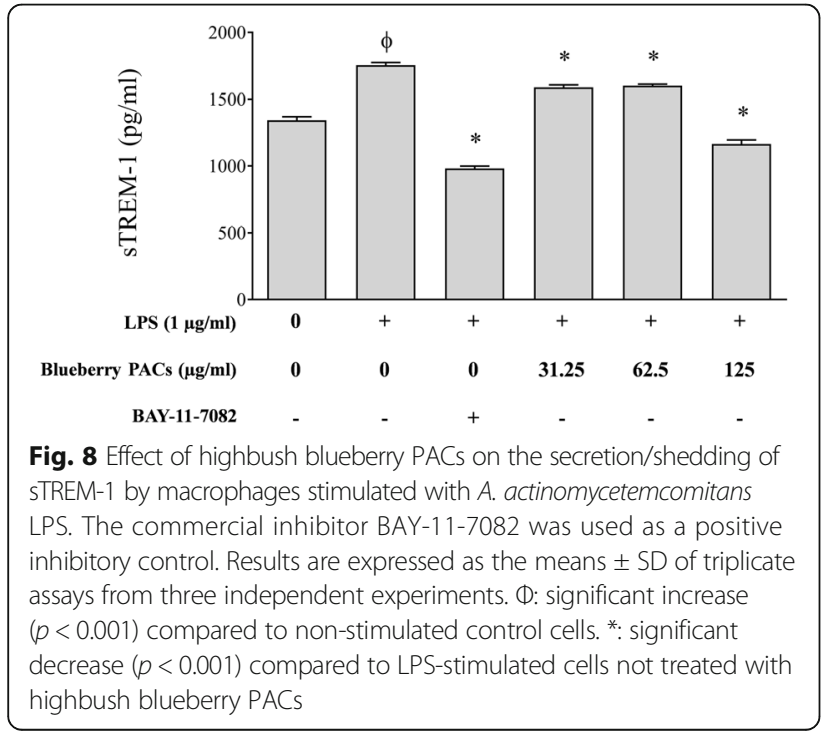

America, has been successfully hybridized with lowbush and rabbiteye blueberry species to create northern and southern varieties, respectively [35]. Many studies have shown that blueberries have beneficial effects on human health, especially with respect to cancers and inflammatory, neurodegenerative, and cardiovascular diseases [36, 37]. The health effects of blueberries have been attributed to their high phenolic acid, catechin (flavanols), and PAC (condensed tannins) content. PACs are oligomers or polymers of polyhydroxy flavan-3-ol units such as (+)-cathechin and (-)-epicathechin [38]. According to $\mathrm{Gu}$ et al., highbush blueberries contain 129-230 mg of PACs per $100 \mathrm{~g}$ [39]. Previous studies have reported that cranberry PACs interfere with the pathogenic properties of periodontopathogens and have anti-inflammatory properties [40]. Cranberry PACs differ from PACs isolated from other berry fruits, including blueberries, since they are mainly composed of epicatechin subunits with at least one intermolecular A-type bond between $\mathrm{O} 7$ and $\mathrm{C} 2$ in addition to the carbon-carbon bond [41]. In the present study, we evaluated the ability of PACs isolated from highbush blueberries to attenuate several major virulence properties of A. actinomycetemcomitans, a Gram-negative bacterium that is strongly associated with localized aggressive periodontitis [2] as well as with extra-oral infections such as infective endocarditis [42], bacterial arthritis [43], and osteomyelitis [44]. We also investigated the effects of blueberry PACs on the integrity of the oral keratinocyte barrier, leukotoxin activity, and the LPS-mediated inflammatory response of monocytes/macrophages.

Although highbush blueberry PACs $(\geq 31.25 \mu \mathrm{g} / \mathrm{ml})$ significantly reduced the growth of $A$. actinomycetemcomitans, they did not completely inhibit growth, even at the highest concentration tested $(500 \mu \mathrm{g} / \mathrm{ml})$. This finding was consistent with previous studies on the antimicrobial activity of blueberry extracts (highbush, 

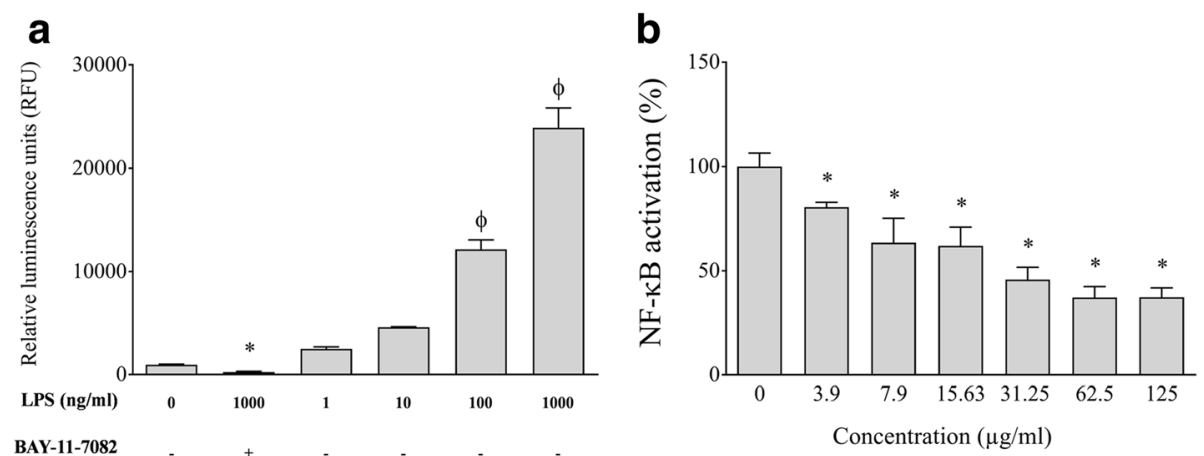

Fig. 9 Effect of A. actinomycetemcomitans LPS in the absence and presence of highbush blueberry PACs on nuclear factor-KB (NF-KB) activation using the U937-3×KB cell model. Panel a Concentration effect of $A$. actinomycetemcomitans LPS on NF-KB activation. Panel $\mathbf{b}$ Inhibitory effect of highbush blueberry PACs on A. actinomycetemcomitans LPS-induced NF-KB activation. A value of 100\% was assigned to the activation obtained with A. actinomycetemcomitans LPS in the absence of highbush blueberry PACs. BAY-11-7082 was used as a positive inhibitory control. Results are expressed as the mean \pm SD of triplicate assays from two independent experiments. $\Phi$ : significant increase $(p<0.001)$ compared with nonstimulated control cells. $*$ : significant decrease $(p<0.001)$ compared with LPS-stimulated cells not treated with highbush blueberry PACS

lowbush) against major human pathogens such as Listeria monocytogenes, Helicobacter pylori, Salmonella typhinurium, Escherichia coli, and Fusobacterium nucleatum [45-49]. Since the bacterial cell membrane is a target for many plant polyphenols, we used a membrane permeabilization assay to show that highbush blueberry PACs caused damage to $A$. actinomycetemcomitans that leads to cell lysis as shown by the release of calcein-AM. A scanning electron microscopic study by Joshi et al. showed that highbush blueberry PACs cause major damage to the cell surface of Cronobacter sakazakii [50].

Oral biofilms are structured microbial communities attached to oral surfaces that enable bacteria to evade immune defenses and resist mechanical removal and chemotherapeutic agents [51]. We showed that highbush blueberry PACs possess marked anti-biofilm activity at concentrations that do not inhibit bacterial growth, almost completely preventing $A$. actinomycetemcomitans biofilm formation at concentrations as low as $31.25 \mu \mathrm{g} /$ $\mathrm{ml}$. The anti-biofilm activity of highbush blueberry PACs was confirmed by scanning electron microscopic observations indicating that they may inhibit the formation and maturation of periodontopathogen biofilms. This result was consistent with our previous study showing that a lowbush blueberry extract inhibited biofilm formation by the periodontopathogen F. nucleatum [49]. In the present study, we showed that highbush blueberry PACs decrease the viability of biofilms, without causing biofilm desorption. The mechanism involved in biofilm killing may be related to the ability of these PACs to alter the integrity of the cell membrane, as reported above.

A. actinomycetemcomitans colonizes the gingival sulcus by adhering to the sulcular/junctional epithelium. From there, it can invade the epithelium, penetrate into the subgingival connective tissue, and induce inflammatory processes [52]. Based on our understanding of bacteria-mediated periodontal tissue destruction, using agents that maintain the integrity of the oral keratinocyte tight junction may be a valuable strategy for preventing periodontal disease. TER measurements are commonly used to assess the integrity of tight junctions. Using this in vitro model, on the one hand, we observed that incubating the oral keratinocytes with A. actinomycetemcomitans (MOIs of $10^{4}$ ) results in an increase in TER values within $8 \mathrm{~h}$. On the other hand, the TER values decreased following longer incubation periods (24, 48, and 72 h). Similar observations were made following apical and basolateral A. actinomycetemcomitans challenges (data not shown) thus suggesting that the initial increase in TER may not be related to deposition of bacteria on the keratinocyte monolayer. Such increase of TER values was also reported in a previous study of Groeger et al. [52] who showed that stimulation of oral keratinocytes with Porphyromonas gingivalis (whole bacteria or supernatant) involved a peak of TER values at $8 \mathrm{~h}$ in both primary and immortalized human oral keratinocytes. It has been proposed that this may reflect a defense reaction of host cells, although the underlying mechanisms are still unknown.

We showed that highbush blueberry PACs significantly and dose-dependently reduce the ability of A. actinomycetemcomitans to damage the integrity of the keratinocyte tight junction. To the best of our knowledge, this is the first time that $A$. actinomycetemcomitans has been shown to decrease TER values and that highbush blueberry PACs can protect the integrity of the oral keratinocyte barrier. Such a bio-protective effect by polyphenols has been previously reported using an intestinal epithelial barrier model. For example, epigallocatechin3-gallate (EGCG), quercetin, and resveratrol, which are 
flavanol-, flavonol-, and stilbene-class polyphenols, respectively, have been reported to protect the barrier function of epithelial intestinal Caco2-cells against indomethacin-induced gastrointestinal damage [53]. Moreover, Park et al. reported that black tea theaflavins increase the integrity of the intestinal barrier by closing the tight junction route in Caco- 2 cells [54]. They showed that theaflavins modulate AMP-activated protein kinase, which results in the enhanced expression of tight junction proteins, including occludin, claudin-1, and zonula occludens-1 [54]. In the present study, the immunofluorescence staining brought evidence that the increased keratinocyte barrier integrity in the presence of PACs may result from ZO-1 and occludin overexpression or redistribution. ZO-1 establishes the linkage between transmembrane proteins and the cytoskeleton, whereas occludin is a membrane protein with two extracellular loops that interact with ZO-1. These proteins are known to play a primary role in the maintenance of the epithelial barrier.

A. actinomycetemcomitans expresses several virulence factors, including LtxA, an exotoxin that appears to play an important role in the etiopathogenesis of localized aggressive periodontitis $[55,56]$. LtxA protects the bacteria from local defense mechanisms by killing leukocytes and disturbing the host response [57, 58]. It is a large pore-forming toxin that belongs to the RTX (Repeats in toxin) family of bacterial proteins [59]. It selectively affects human hematopoietic cells by binding to the lymphocyte function-associated receptor 1 (LFA-1), which disrupts the integrity of the cell membrane [60]. Human monocytes/macrophages are highly sensitive to LtxA. Kelk et al. reported that the LtxA-induced cell death of macrophages occurs through a process leading to a specific and excessive pro-inflammatory response involving the secretion of IL-1 $\beta$ and IL-18 [61]. Since leukotoxicity is correlated with attachment loss in teenagers affected with localized aggressive periodontitis [62], LtxA may be a promising target for future therapeutics. We showed that high concentrations of highbush blueberry PACs completely protect macrophagelike cells. To the best of our knowledge, this is the first report on the potential of polyphenols to neutralize the leukotoxin activity of A. actinomycetemcomitans.

Periodontal health requires a balanced immunoinflammatory state that maintains a host-bacteria homeostasis in the periodontium [63]. Pro-inflammatory cytokines with potent pro-resorptive effects such as IL- $1 \beta$, TNF- $\alpha$, and IL- 6 are strongly upregulated by $A$. actinomycetemcomitans and likely promote osteoclast formation and bone resorption [64-68]. A. actinomycetemcomitans LPS is a key virulence factor that upregulates the pathophysiologic inflammatory response [69]. Such an immune response perturbs normal periodontal tissue remodeling/turnover and ultimately has deleterious effects on periodontal tissue homeostasis [70]. The LPS/TLR4 signaling pathway induces the activation of several innate immune pathways such as phagocytosis and the overexpression of pro-inflammatory chemokines, cytokines and co-stimulatory molecules, which leads to the initiation of the inflammatory response [71-73]. We used macrophage-like cells to show that highbush blueberry PACs significantly reduce the secretion of major pro-inflammatory cytokines (IL- $1 \beta$, TNF- $\alpha$, IL-6, and CXCL8) induced by $A$. actinomycetemcomitans LPS. The anti-inflammatory property of PACs is of utmost importance given that periodontitis is caused by inflammophilic pathogens that take advantage of the inflammatory environment in periodontal pockets [74]. The efficient regulation of inflammation is thus likely to control both dysbiosis and disease progression.

The activation of TREM-1 expressed on neutrophils and monocytes amplifies the production of various proinflammatory cytokines, chemokines, and cell surface receptors [75]. Moreover, bacterial products such as LPS induce the release of the soluble form of TREM-1 (sTREM-1) in humans [76]. sTREM-1 has also been detected in gingival crevicular fluid and is present in higher concentrations in diseased periodontal sites [77]. However, the exact role of sTREM-1 in the inflammatory cascade remains unclear. Some studies have shown that the upregulation of sTREM-1 production is mediated by bacterial challenges [78] and have concluded that it may be a specific marker of infections in various pathologies [78, 79]. When sTREM-1 is detected in serum it may have been released by circulating leukocytes during the course of a systemic infection [78]. To the best of our knowledge, no studies have investigated the potential of A. actinomycetemcomitans LPS to induce the secretion/ shedding of sTREM-1. Interestingly, we found that highbush blueberry PACs significantly reduce sTREM-1 levels in a macrophage model stimulated with A. actinomycetemcomitans LPS. In a recent study, we reported that tea polyphenols also reduce the secretion of sTREM-1 induced by F. nucleatum [49].

Periodontal inflammation associated with persistent chronic bacterial infections in subgingival sites upregulates the expression and activity of matrix metalloproteinases (MMPs), which contribute to the progressive breakdown of periodontal supporting tissue [80]. MMPs, a large family of calcium-dependent zinc-containing endopeptidases, are involved in tissue remodeling and the degradation of extracellular matrix proteins, including collagens, elastin, matrix glycoprotein, and proteoglycans [81]. While the transcription of MMP genes is rather low in healthy periodontal tissue, the secretion of specific MMPs is up-regulated by various cytokines during periodontitis. For example, IL-1 $\beta$ and TNF- $\alpha$ stimulate 
the secretion of MMP-3, -8 , and -9 by gingival fibroblasts [82]. Moreover, A. actinomycetemcomitans has been reported to induce the expression of MMP-1, -2 , and -9 in a murine model [83] and in human peripheral blood monocytes [84]. MMPs are considered promising targets for the treatment of periodontal disease due to their involvement in the inflammatory destruction of periodontal attachment. Interestingly, we showed that highbush blueberry PACs reduce MMP-3 and MMP-9 secretion by LPS-stimulated macrophages. MMP-3 (stromelysin) and MMP-9 (gelatinase B) have been strongly associated with the progression of periodontitis [80]. On the one hand, MMP-3 contributes to tissue remodeling and destruction, induces apoptosis, promotes cell differentiation, and activates other latent MMPs such as MMP-8 and MMP-9 [80, 85, 86]. On the other hand, MMP-9 regulates numerous cell activities, such as cell-cell contact, tissue remodeling, cell migration, and cellular differentiation [87].

Lastly, many studies on A. actinomycetemcomitans in a rodent model of experimental periodontitis have provided evidence that the NF- $\mathrm{kB}$ signaling pathway is involved in the host inflammatory response [70, 88-90]. The activation of NF- $\mathrm{kB}$ by nuclear translocation plays a central role in inflammation through its ability to induce the transcription of pro-inflammatory genes [91]. NF- $\mathrm{kB}$ activation has been reported to contribute to the pathogenesis of many chronic inflammatory diseases, including rheumatoid arthritis, inflammatory bowel disease, asthma, and oral lichens planus [92-94]. A recent study involving healthy controls and patients with chronic periodontitis showed that the activation of NF- $k B$ ( 550 / p65) is significantly upregulated in periodontal disease tissues, suggesting that NF- $\mathrm{kB}$ inhibitors may be promising agents for managing periodontitis [95]. In this context, we used the U937-3хкB cell model to show that highbush blueberry PACs inhibit NF- $\mathrm{kB}$ activation induced by $A$. actinomycetemcomitans LPS; this is likely, at least in part, involved in the reduced secretion of inflammatory mediators by macrophages.

\section{Conclusions}

In conclusion, the antibacterial and anti-inflammatory properties of highbush blueberry PACs and their ability protect the integrity of the oral keratinocyte barrier and to neutralize leukotoxin activity suggest that they may be promising candidates for novel therapeutic agents. The beneficial properties of blueberry PACs identified in this study should open the door for future clinical trials on the potential of these bioactive PACs for periodontal disease prevention and/or treatment. These studies should evaluate the impact of blueberry consumption (fruit, juice, extract) on the severity and progression of periodontal disease. Given that highbush blueberries contain 129-230 mg of PACs per $100 \mathrm{~g}$ (fresh weight food) [39], it is believed that effective concentrations could be achieved in the oral cavity. Moreover, studies on the benefits provided by the use of oral-hygiene products (mouthrinses and chewing gums) or slow periodontal-release devices (to be inserted in diseased periodontal sites) containing bioactive PACs are also of high interest.

\section{Acknowledgements \\ We thank S. Groeger and J. Meyle (Department of Periodontology, Justus- Liebig-University Giessen, Germany) as well as R. Blomhoff and H. Carlsen (University of Oslo, Norway) for kindly providing the B11 keratinocyte cell line and the U937-3xkB-LUC cell line, respectively. We are also grateful to A. Howell (Philip E. Marucci Center for Blueberry and Cranberry Research, State University of New Jersey, USA) for providing the highbush blueberry PACs.}

\section{Funding}

This work was financially supported by the US Highbush Blueberry Council (Folsom, CA, USA).

\section{Availability of data and materials}

The datasets used and/or analysed during the current study are available from the corresponding author on reasonable request.

\section{Authors' contributions}

$A B L$ and $G L$ conducted the experiments, $A B L, G L$ and $D G$ analyzed the results. $\mathrm{DG}$ contributed reagents/materials. The manuscript was written by $\mathrm{ABL}$ and $\mathrm{DG}$. All authors read and approved the final manuscript.

Ethics approval and consent to participate

Not applicable

Consent for publication

Not applicable

\section{Competing interests}

The authors declare that they have no competing interests.

\section{Publisher's Note}

Springer Nature remains neutral with regard to jurisdictional claims in published maps and institutional affiliations.

Received: 1 June 2017 Accepted: 27 December 2017

Published online: 10 January 2018

\section{References}

1. Socransky SS, Haffajee AD. The bacterial etiology of destructive periodontal disease: current concepts. J Periodontol. 1992;63(4 Suppl):322-31.

2. Fine DH, Markowitz K, Furgang D, Fairlie K, Ferrandiz J, Nasri C, McKiernan M, Gunsolley J. Aggregatibacter actinomycetemcomitans and its relationship to initiation of localized aggressive periodontitis: longitudinal cohort study of initially healthy adolescents. J Clin Microbiol. 2007:45(12):3859-69.

3. Zambon JJ, Christersson LA, Slots J. Actinobacillus actinomycetemcomitans in human periodontal disease. Prevalence in patient groups and distribution of biotypes and serotypes within families. J Periodontol. 1983;54(12):707-11.

4. van Winkelhoff AJ, Slots J. Actinobacillus actinomycetemcomitans and Porphyromonas gingivalis in nonoral infections. Periodontol 2000. 1999;20:122-35.

5. Henderson B, Ward JM, Ready D. Aggregatibacter (Actinobacillus) actinomycetemcomitans: a triple $A^{*}$ periodontopathogen? Periodontol 2000. 2010;54(1):78-105

6. Rahamat-Langendoen JC, van Vonderen MG, Engstrom LJ, Manson WL, van Winkelhoff AJ, Mooi-Kokenberg EA. Brain abscess associated with Aggregatibacter actinomycetemcomitans: case report and review of literature. J Clin Periodontol. 2011:38(8):702-6.

7. Fine DH, Furgang D, Kaplan J, Charlesworth J, Figurski DH. Tenacious adhesion of Actinobacillus actinomycetemcomitans strain CU1000 to salivarycoated hydroxyapatite. Arch Oral Biol. 1999;44(12):1063-76. 
8. Kachlany SC, Planet PJ, Desalle R, Fine DH, Figurski DH, Kaplan JB. flp-1, the first representative of a new pilin gene subfamily, is required for nonspecific adherence of Actinobacillus actinomycetemcomitans. Mol Microbiol. 2001:40(3):542-54.

9. Fine DH, Goncharoff P, Schreiner H, Chang KM, Furgang D, Figurski D. Colonization and persistence of rough and smooth colony variants of Actinobacillus actinomycetemcomitans in the mouths of rats. Arch Oral Biol. 2001;46(11):1065-78.

10. Schreiner HC, Sinatra K, Kaplan JB, Furgang D, Kachlany SC, Planet PJ, Perez BA, Figurski DH, Fine DH. Tight-adherence genes of Actinobacillus actinomycetemcomitans are required for virulence in a rat model. Proc Natl Acad Sci U S A. 2003;100(12):7295-300.

11. Takahashi N, Ishihara K, Kato T, Okuda K. Susceptibility of Actinobacillus actinomycetemcomitans to six antibiotics decreases as biofilm matures. J Antimicrob Chemother. 2007;59(1):59-65.

12. Aberg CH, Kelk P, Johansson A. Aggregatibacter actinomycetemcomitans: virulence of its leukotoxin and association with aggressive periodontitis. Virulence. 2015;6(3):188-95.

13. Groeger SE, Meyle J. Epithelial barrier and oral bacterial infection. Periodontol 2000. 2015;69(1):46-67.

14. Hasturk H, Kantarci A. Activation and resolution of periodontal inflammation and its systemic impact. Periodontol 2000. 2015;69(1):255-73.

15. Bosshardt DD, Lang NP. The junctional epithelium: from health to disease. J Dent Res. 2005;84(1):9-20.

16. Hasturk H, Kantarci A, Van Dyke TE. Oral inflammatory diseases and systemic inflammation: role of the macrophage. Front Immunol. 2012;3:118.

17. Park SR, Kim DJ, Han SH, Kang MJ, Lee JY, Jeong YJ, Lee SJ, Kim TH, Ahn SG, Yoon $\mathrm{JH}$, et al. Diverse toll-like receptors mediate cytokine production by Fusobacterium nucleatum and Aggregatibacter actinomycetemcomitans in macrophages. Infect Immun. 2014;82(5):1914-20.

18. Hannas AR, Pereira JC, Granjeiro JM, Tjaderhane L. The role of matrix metalloproteinases in the oral environment. Acta Odontol Scand. 2007;65(1):1-13.

19. Liu YC, Lerner UH, Teng YT. Cytokine responses against periodontal infection: protective and destructive roles. Periodontol 2000. 2010;52(1):163-206.

20. Kaye EK. Nutrition, dietary guidelines and optimal periodontal health. Periodontol 2000. 2012;58(1):93-111.

21. Kang J, Thakali KM, Jensen GS, Wu X. Phenolic acids of the two major blueberry species in the US Market and their antioxidant and antiinflammatory activities. Plant Foods Hum Nutr. 2015;70(1):56-62.

22. Papandreou MA, Dimakopoulou A, Linardaki ZI, Cordopatis P, Klimis-Zacas D, Margarity M, Lamari FN. Effect of a polyphenol-rich wild blueberry extract on cognitive performance of mice, brain antioxidant markers and acetylcholinesterase activity. Behav Brain Res. 2009;198(2):352-8.

23. Neto CC. Cranberry and blueberry: evidence for protective effects against cancer and vascular diseases. Mol Nutr Food Res. 2007;51(6):652-64.

24. Martineau LC, Couture A, Spoor D, Benhaddou-Andaloussi A, Harris C, Meddah B, Leduc C, Burt A, Vuong T, Mai Le P, et al. Anti-diabetic properties of the Canadian lowbush blueberry Vaccinium angustifolium Ait. Phytomedicine. 2006;13(9-10):612-23.

25. Wu X, Beecher GR, Holden JM, Haytowitz DB, Gebhardt SE, Prior RL. Concentrations of anthocyanins in common foods in the United States and estimation of normal consumption. J Agric Food Chem. 2006;54(11): 4069-75.

26. Harnly JM, Doherty RF, Beecher GR, Holden JM, Haytowitz DB, Bhagwat S, Gebhardt S. Flavonoid content of U.S. fruits, vegetables, and nuts. J Agric Food Chem. 2006;54(26):9966-77.

27. Howell AB, Reed JD, Krueger CG, Winterbottom R, Cunningham DG, Leahy M. A-type cranberry proanthocyanidins and uropathogenic bacterial antiadhesion activity. Phytochemistry. 2005;66(18):2281-91.

28. Darveau RP, Hancock RE. Procedure for isolation of bacterial lipopolysaccharides from both smooth and rough Pseudomonas aeruginosa and Salmonella typhimurium strains. J Bacteriol. 1983;155(2):831-8.

29. Morin MP, Bedran TB, Fournier-Larente J, Haas B, Azelmat J, Grenier D. Green tea extract and its major constituent epigallocatechin-3-gallate inhibit growth and halitosis-related properties of Solobacterium moorei. BMC Complement Altern Med. 2015;15:48.

30. Groger S, Michel J, Meyle J. Establishment and characterization of immortalized human gingival keratinocyte cell lines. J Periodontal Res. 2008;43(6):604-14.

31. Gumbiner B, Simons K. A functional assay for proteins involved in establishing an epithelial occluding barrier: identification of a uvomorulinlike polypeptide. J Cell Biol. 1986;102(2):457-68.
32. Kachlany SC, Fine DH, Figurski DH. Purification of secreted leukotoxin (LtxA) from Actinobacillus actinomycetemcomitans. Protein Expr Purif. 2002;25(3): 465-71.

33. Rovera G, Santoli D, Damsky C. Human promyelocytic leukemia cells in culture differentiate into macrophage-like cells when treated with a phorbol diester. Proc Natl Acad Sci U S A. 1979;76(6):2779-83.

34. Carlsen H, Moskaug JO, Fromm SH, Blomhoff R. In vivo imaging of NFkappa B activity. J Immunol. 2002;168(3):1441-6.

35. Petrova VI, Kennelly EJ. Blueberries: a "Super Fruit" complement to cereals. Cereal Foods World. 2013;58(1):13-7.

36. Giacalone M, Di Sacco F, Traupe I, Topini R, Forfori F, Giunta F. Antioxidant and neuroprotective properties of blueberry polyphenols: a critical review. Nutr Neurosci. 2011;14(3):119-25.

37. Torri E, Lemos M, Caliari V, Kassuya CA, Bastos JK, Andrade SF. Antiinflammatory and antinociceptive properties of blueberry extract (Vaccinium corymbosum). J Pharm Pharmacol. 2007:59(4):591-6.

38. Yamakoshi J, Saito M, Kataoka S, Kikuchi M. Safety evaluation of proanthocyanidinrich extract from grape seeds. Food Chem Toxicol. 2002;40(5):599-607.

39. Gu L, Kelm MA, Hammerstone JF, Beecher G, Holden J, Haytowitz D, Gebhardt S, Prior RL. Concentrations of proanthocyanidins in common foods and estimations of normal consumption. J Nutr. 2004;134(3):613-7.

40. Feghali K, Feldman M, La VD, Santos J, Grenier D. Cranberry proanthocyanidins: natural weapons against periodontal diseases. J Agric Food Chem. 2012;60(23):5728-35

41. Foo $L Y, L u Y$, Howell $A B$, Vorsa N. A-Type proanthocyanidin trimers from cranberry that inhibit adherence of uropathogenic P-fimbriated Escherichia coli. J Nat Prod. 2000;63(9):1225-8.

42. Nakano K, Inaba H, Nomura R, Nemoto H, Tamura K, Miyamoto E, Yoshioka H, Taniguchi K, Amano A, Ooshima T. Detection and serotype distribution of Actinobacillus actinomycetemcomitans in cardiovascular specimens from Japanese patients. Oral Microbiol Immunol. 2007;22(2):136-9.

43. Cuende E, de Pablos M, Gomez M, Burgaleta S, Michaus L, Vesga JC. Coexistence of pseudogout and arthritis due to Actinobacillus actinomycetemcomitans. Clin Infect Dis. 1996;23(3):657-8.

44. Antony B, Thomas S, Chandrashekar SC, Kumar MS, Kumar V. Osteomyelitis of the mandible due to Aggregatibacter (Actinobacillus) actinomycetemcomitans. Indian J Pathol Microbiol. 2009;52(1):115-6.

45. Chatterjee A, Yasmin T, Bagchi D, Stohs SJ. Inhibition of Helicobacter pylori in vitro by various berry extracts, with enhanced susceptibility to clarithromycin. Mol Cell Biochem. 2004;265(1-2):19-26.

46. Lacombe A, Wu VC, White J, Tadepalli S, Andre EE. The antimicrobial properties of the lowbush blueberry (Vaccinium angustifolium) fractional components against foodborne pathogens and the conservation of probiotic Lactobacillus rhamnosus. Food Microbiol. 2012;30(1):124-31.

47. Ofek I, Goldhar J, Sharon N. Anti-Escherichia coli adhesin activity of cranberry and blueberry juices. Adv Exp Med Biol. 1996;408:179-83.

48. Park YJ, Biswas R, Phillips RD, Chen J. Antibacterial activities of blueberry and muscadine phenolic extracts. J Food Sci. 2011;76(2):M101-5.

49. Ben Lagha A, Dudonne S, Desjardins Y, Grenier D. Wild blueberry (Vaccinium angustifolium Ait.) polyphenols target Fusobacterium nucleatum and the host inflammatory response: potential innovative molecules for treating periodontal diseases. J Agric Food Chem. 2015;63(31):6999-7008.

50. Joshi SS, Howell AB, D'Souza DH. Cronobacter sakazakii reduction by blueberry proanthocyanidins. Food Microbiol. 2014;39:127-31.

51. Wilson M. Bacterial biofilms and human disease. Sci Prog. 2001;84(Pt 3):235-54.

52. Groeger S, Doman E, Chakraborty T, Meyle J. Effects of Porphyromonas gingivalis infection on human gingival epithelial barrier function in vitro. Eur J Oral Sci. 2010;118(6):582-9.

53. Carrasco-Pozo C, Morales P, Gotteland M. Polyphenols protect the epithelial barrier function of Caco-2 cells exposed to indomethacin through the modulation of occludin and zonula occludens-1 expression. J Agric Food Chem. 2013;61(22):5291-7.

54. Park HY, Kunitake Y, Hirasaki N, Tanaka M, Matsui T. Theaflavins enhance intestinal barrier of Caco-2 cell monolayers through the expression of AMPactivated protein kinase-mediated Occludin, Claudin-1, and ZO-1. Biosci Biotechnol Biochem. 2015;79(1):130-7.

55. Fine DH, Kaplan JB, Kachlany SC, Schreiner HC. How we got attached to Actinobacillus actinomycetemcomitans: a model for infectious diseases. Periodontol 2000. 2006:42:114-57.

56. Kachlany SC. Aggregatibacter actinomycetemcomitans leukotoxin: from threat to therapy. J Dent Res. 2010;89(6):561-70. 
57. Guthmiller JM, Lally ET, Korostoff J. Beyond the specific plaque hypothesis: are highly leukotoxic strains of Actinobacillus actinomycetemcomitans a paradigm for periodontal pathogenesis? Crit Rev Oral Biol Med. 2001;12(2):116-24.

58. Johansson A, Sandstrom G, Claesson R, Hanstrom L, Kalfas S. Anaerobic neutrophil-dependent killing of Actinobacillus actinomycetemcomitans in relation to the bacterial leukotoxicity. Eur J Oral Sci. 2000;108(2):136-46.

59. Linhartova I, Bumba L, Masin J, Basler M, Osicka R, Kamanova J, Prochazkova K, Adkins I, Hejnova-Holubova J, Sadilkova L, et al. RTX proteins: a highly diverse family secreted by a common mechanism. FEMS Microbiol Rev. 2010;34(6):1076-112

60. Lally ET, Hill RB, Kieba IR, Korostoff J. The interaction between RTX toxins and target cells. Trends Microbiol. 1999;7(9):356-61.

61. Kelk P, Abd H, Claesson R, Sandstrom G, Sjostedt A, Johansson A. Cellular and molecular response of human macrophages exposed to Aggregatibacter actinomycetemcomitans leukotoxin. Cell Death Dis. 2011:2:e126.

62. Hoglund Aberg C, Kwamin F, Claesson R, Dahlen G, Johansson A, Haubek D. Progression of attachment loss is strongly associated with presence of the JP2 genotype of Aggregatibacter actinomycetemcomitans: a prospective cohort study of a young adolescent population. J Clin Periodontol. 2014;41(3):232-41.

63. Hajishengallis $\mathrm{G}$. Periodontitis: from microbial immune subversion to systemic inflammation. Nat Rev Immunol. 2015;15(1):30-44.

64. Ishimi Y, Miyaura C, Jin CH, Akatsu T, Abe E, Nakamura Y, Yamaguchi A, Yoshiki S, Matsuda T, Hirano T, et al. IL-6 is produced by osteoblasts and induces bone resorption. J Immunol. 1990;145(10):3297-303.

65. Assuma R, Oates T, Cochran D, Amar S, Graves DT. IL-1 and TNF antagonists inhibit the inflammatory response and bone loss in experimental periodontitis. J Immunol. 1998;160(1):403-9.

66. Chiang CY, Kyritsis G, Graves DT, Amar S. Interleukin-1 and tumor necrosis factor activities partially account for calvarial bone resorption induced by local injection of lipopolysaccharide. Infect Immun. 1999;67(8):4231-6.

67. Zhang YH, Heulsmann A, Tondravi MM, Mukherjee A, Abu-Amer Y. Tumor necrosis factor-alpha (TNF) stimulates RANKL-induced osteoclastogenesis via coupling of TNF type 1 receptor and RANK signaling pathways. J Biol Chem. 2001:276(1):563-8.

68. Hotokezaka H, Sakai E, Ohara N, Hotokezaka Y, Gonzales C, Matsuo K, Fujimura Y, Yoshida N, Nakayama K. Molecular analysis of RANKLindependent cell fusion of osteoclast-like cells induced by TNF-alpha, lipopolysaccharide, or peptidoglycan. J Cell Biochem. 2007;101(1):122-34.

69. Lima HR, Gelani V, Fernandes AP, Gasparoto TH, Torres SA, Santos CF, Garlet GP, da Silva JS, Campanelli AP. The essential role of toll like receptor-4 in the control of Aggregatibacter actinomycetemcomitans infection in mice. J Clin Periodontol. 2010;37(3):248-54.

70. Herbert BA, Novince CM, Kirkwood KL. Aggregatibacter actinomycetemcomitans, a potent immunoregulator of the periodontal host defense system and alveolar bone homeostasis. Mol Oral Microbiol. 2016:31(3):207-27.

71. Underhill DM, Ozinsky A, Hajjar AM, Stevens A, Wilson CB, Bassetti M, Aderem A. The Toll-like receptor 2 is recruited to macrophage phagosomes and discriminates between pathogens. Nature. 1999;401(6755):811-5.

72. Madianos PN, Bobetsis YA, Kinane DF. Generation of inflammatory stimuli: how bacteria set up inflammatory responses in the gingiva. J Clin Periodontol. 2005;32(Suppl 6):57-71.

73. Elson G, Dunn-Siegrist I, Daubeuf B, Pugin J. Contribution of Toll-like receptors to the innate immune response to gram-negative and grampositive bacteria. Blood. 2007;109(4):1574-83.

74. Hajishengallis $\mathrm{G}$. The inflammophilic character of the periodontitisassociated microbiota. Mol Oral Microbiol. 2014;29(6):248-57.

75. Schenk M, Bouchon A, Seibold F, Mueller C. TREM-1-expressing intestinal macrophages crucially amplify chronic inflammation in experimental colitis and inflammatory bowel diseases. J Clin Invest. 2007;117(10):3097-106.

76. Gibot S. Clinical review: role of triggering receptor expressed on myeloid cells-1 during sepsis. Crit Care. 2005;9(5):485-9.

77. Bisson C, Massin F, Lefevre PA, Thilly N, Miller N, Gibot S. Increased gingival crevicular fluid levels of soluble triggering receptor expressed on myeloid cells (sTREM) -1 in severe periodontitis. J Clin Periodontol. 2012:39(12):1141-8.

78. Gibot S, Kolopp-Sarda MN, Bene MC, Bollaert PE, Lozniewski A, Mory F, Levy $B$, Faure GC. A soluble form of the triggering receptor expressed on myeloid cells-1 modulates the inflammatory response in murine sepsis. J Exp Med. 2004;200(11):1419-26.

79. Gibot S, Cravoisy A. Soluble form of the triggering receptor expressed on myeloid cells-1 as a marker of microbial infection. Clin Med Res. 2004;2(3):181-7.
80. Sorsa T, Tjaderhane L, Konttinen YT, Lauhio A, Salo T, Lee HM, Golub LM, Brown DL, Mantyla P. Matrix metalloproteinases: contribution to pathogenesis, diagnosis and treatment of periodontal inflammation. Ann Med. 2006:38(5):306-21.

81. Verma RP, Hansch C. Matrix metalloproteinases (MMPs): chemical-biological functions and (Q)SARs. Bioorg Med Chem. 2007;15(6):2223-68.

82. Cekici A, Kantarci A, Hasturk H, Van Dyke TE. Inflammatory and immune pathways in the pathogenesis of periodontal disease. Periodontol 2000 2014;64(1):57-80.

83. Garlet GP, Cardoso CR, Silva TA, Ferreira BR, Avila-Campos MJ, Cunha FQ, Silva JS. Cytokine pattern determines the progression of experimental periodontal disease induced by Actinobacillus actinomycetemcomitans through the modulation of MMPs, RANKL, and their physiological inhibitors. Oral Microbiol Immunol. 2006;21(1):12-20.

84. Serra R, Al-Saidi AG, Angelov N, Nares S. Suppression of LPS-induced matrixmetalloproteinase responses in macrophages exposed to phenytoin and its metabolite, 5-(p-hydroxyphenyl-), 5-phenylhydantoin. J Inflamm (Lond). 2010;7:48

85. Sorsa T, Tjaderhane L, Salo T. Matrix metalloproteinases (MMPs) in oral diseases. Oral Dis. 2004;10(6):311-8.

86. Beklen A, Tuter G, Sorsa T, Hanemaaijer R, Virtanen I, Tervahartiala T, Konttinen YT. Gingival tissue and crevicular fluid co-operation in adult periodontitis. J Dent Res. 2006;85(1):59-63.

87. Vandooren J, Van den Steen PE, Opdenakker G. Biochemistry and molecular biology of gelatinase B or matrix metalloproteinase-9 (MMP-9): the next decade. Crit Rev Biochem Mol Biol. 2013;48(3):222-72.

88. Li Q, Yu H, Zinna R, Martin K, Herbert B, Liu A, Rossa C Jr, Kirkwood KL. Silencing mitogen-activated protein kinase-activated protein kinase-2 arrests inflammatory bone loss. J Pharmacol Exp Ther. 2011;336(3):633-42.

89. Yu H, Li Q, Herbert B, Zinna R, Martin K, Junior CR, Kirkwood KL. Antiinflammatory effect of MAPK phosphatase-1 local gene transfer in inflammatory bone loss. Gene Ther. 2011;18(4):344-53.

90. Dunmyer J, Herbert B, Li Q, Zinna R, Martin K, Yu H, Kirkwood KL. Sustained mitogen-activated protein kinase activation with Aggregatibacter actinomycetemcomitans causes inflammatory bone loss. Mol Oral Microbiol. 2012;27(5):397-407.

91. Barnes PJ, Karin M. Nuclear factor-kappaB: a pivotal transcription factor in chronic inflammatory diseases. N Engl J Med. 1997;336(15):1066-71.

92. Hart LA, Krishnan VL, Adcock IM, Barnes PJ, Chung KF. Activation and localization of transcription factor, nuclear factor-kappaB, in asthma. Am J Respir Crit Care Med. 1998;158(5 Pt 1):1585-92.

93. Ardite E, Panes J, Miranda M, Salas A, Elizalde JI, Sans M, Arce Y, Bordas JM, Fernandez-Checa JC, Pique JM. Effects of steroid treatment on activation of nuclear factor kappaB in patients with inflammatory bowel disease. $\mathrm{Br}\rfloor$ Pharmacol. 1998;124(3):431-3.

94. Santoro A, Majorana A, Bardellini E, Festa S, Sapelli P, Facchetti F. NF-kappaB expression in oral and cutaneous lichen planus. J Pathol. 2003;201(3):466-72.

95. Ambili R, Santhi WS, Janam P, Nandakumar K, Pillai MR. Expression of activated transcription factor nuclear factor-kappaB in periodontally diseased tissues. J Periodontol. 2005;76(7):1148-53.

\section{Submit your next manuscript to BioMed Central and we will help you at every step:}

- We accept pre-submission inquiries

- Our selector tool helps you to find the most relevant journal

- We provide round the clock customer support

- Convenient online submission

- Thorough peer review

- Inclusion in PubMed and all major indexing services

- Maximum visibility for your research

Submit your manuscript at www.biomedcentral.com/submit 